\section{PATHWAYS FOR REDUCING MILITARY SPENDING IN POST-CIVIL CONFLICT SETTINGS}

DIEGO LOPES DA SILVA, NAN TIAN AND ALEXANDRA MARKSTEINER

\section{Introduction}

The damage caused by a civil conflict endures long after the fighting ends. The aftermath of armed conflict is often marked by lower educational attainment, increased poverty and undernourishment. ${ }^{1}$ Among the many legacies of a civil conflict, high military spending is certainly a common one. ${ }^{2}$ The average military burdens-military spending as a share of gross domestic product (GDP) - of peaceful and post-conflict societies differ by 1.4 percentage points. ${ }^{3}$ This difference is particularly consequential. Reducing military spending could yield valuable economic gains and further contribute to the recovery of post-conflict societies. ${ }^{4}$

However, little is known about the conditions that enable military spending reductions in a conflict's aftermath. Evidence is still incipient and points to different conclusions. This SIPRI Insights on Peace and Security revisits the issue and provides a comparison of post-civil conflict conditions and military burden outcomes. It builds on a comparative analysis of 19 post-civil conflict episodes between 1970 and 2020 (the latest year for which military spending data is available), as well as three detailed case studies, to identify common pathways to post-civil conflict military burden reductions.

This research finds that credible commitments to peace by the opposing sides, the organization of post-conflict elections and regional stability are the main factors explaining variations in post-civil conflict military

\footnotetext{
${ }^{1}$ Ghobarah, H. A., Huth, P. and Russett, B., 'Civil wars kill and maim people-long after the shooting stops', American Political Science Review, vol. 97, no. 2 (2003), pp. 189-202; and Akresh, R. and de Walque, D., 'Armed conflict and schooling: Evidence from the 1994 Rwandan genocide', Policy Research Working Paper no. 4606 (World Bank: Washington, DC, 2008).

${ }^{2}$ Collier, P. et al., Breaking the Conflict Trap: Civil War and Development Policy, World Bank Policy Research Report (World Bank and Oxford University Press: Washington, DC, and Oxford, 2003); and Hoeffler, A., Ijiaz, S. S. and von Billerbeck, S., 'Post-conflict recovery and peacebuilding', World Bank, World Development Report 2011, Background Paper, 10 Oct. 2010.

${ }^{3}$ Collier, P. and Hoeffler, A., 'Military expenditure in post-conflict societies', Economics of Governance, vol. 7, no.1 (2006), pp. 89-107.

${ }^{4}$ Dunne, J. P. and Tian, N., 'Military expenditure and economic growth: A survey', Economics of Peace and Security Journal, vol. 8, no. 1 (2013), pp. 5-11; and Brauer. J., Dunne, J. P. and Tian, N., 'Towards demilitarisation? The military expenditure-development nexus revisited, ed. R. Matthews, The Political Economy of Defence (Cambridge University Press: Cambridge, 2019), pp. 90-119.
}

\section{SUMMARY}

- High military spending is a common and consequential legacy of civil conflict. Reducing military spending can yield valuable economic gains and further contribute to the recovery of post-civil conflict societies. However, little is known about the conditions that enable military spending reductions in a conflict's aftermath.

This SIPRI Insights on Peace and Security tackles this issue and provides a comparison of post-civil conflict conditions and military burden-military spending as a share of gross domestic product-outcomes. It builds on a comparative analysis of 19 post-civil conflict episodes between 1970 and $\mathbf{2 0 2 0}$, as well as three detailed case studies, to identify common pathways to post-civil conflict military burden reductions. This research finds that reductions in military burden usually follow peace agreements that encompass trustworthy and legitimate verification mechanisms, the strengthening of institutional means to resolve grievances, and improvements in relations with neighbouring countries. 
spending. Simply put, reductions in military burden usually follow peace agreements that encompass trustworthy and legitimate verification mechanisms, the strengthening of institutional means to resolve grievances, and improvements in relations with neighbouring countries.

These findings are relevant to ongoing efforts, most notably at the United Nations, to curb rising military expenditure. In 2020, for example, the Secretary-General's report on women, peace and security called for evidencebased policy recommendations to reduce excessive military expenditure. ${ }^{5}$ While the goal of reducing excessive military spending is global, efforts to find solutions must take account of the vastly different contexts in which countries find themselves. The study presented in this paper considers this important nuance and presents evidence on pathways to reduce military spending in conflict-affected countries.

The next section (section II) summarizes the available evidence on conflict termination and military spending and introduces this study's contribution. Section III outlines the analytical strategy, explores the cases and describes working definitions. It highlights five conflict termination types (i.e. ways in which a conflict ends), with a focus on peace agreements and their various characteristics. Section IV compares the conflict termination conditions of the 19 post-civil conflict episodes analysed by this study and their respective military burden trajectories. It identifies the most common pathway to post-civil conflict military burden reductions. Section V complements the comparative analysis with detailed case studies on Sierra Leone, Nepal and Nicaragua. The concluding section (section VI) synthesizes the findings and discusses some of their limitations.

\section{Military spending in post-civil conflict settings}

Military spending in post-civil conflict settings remains an underresearched topic. In the literature, the issue is often secondary with only a handful of works tackling it directly. Collier and Hoeffler authored the most well-known work on the topic. ${ }^{6}$ They find that high military spending in post-conflict settings increases the likelihood of conflict recurrence in the following decade. The authors argue that post-conflict military spending levels can be seen as a signal of the government's intention either to honour or renege on a peace settlement. This means that rebels could perceive high levels of military spending as a threat, which may unintentionally induce them to pre-emptively attack the government before their military capability withers away. To avoid such an outcome, Collier suggests that post-conflict governments should reduce military spending substantially as soon as possible. ${ }^{7}$

This is no simple task, however. A wide array of factors may inhibit a smooth transition to a lower level of military spending. Of those, the problem of obtaining and maintaining credible commitments to peace is paramount. In the aftermath of a civil conflict, the former belligerents often fear that

\footnotetext{
${ }^{5}$ United Nations, Security Council, Report of the Secretary-General on Women, Peace and Security, S/2020/946, 25 Sep. 2020, para. 113.

${ }^{6}$ Collier and Hoeffler (note 3).

${ }^{7}$ Collier, P., 'Post-conflict recovery: How should policies be distinctive?', Centre for the Study of African Economies, Department of Economics, Oxford University, May 2007.
} 
the other party will renege on the terms of a peace settlement in the future. ${ }^{8}$ Without credible commitments to peace, the government is more likely to maintain military spending close to wartime levels and rebels are less likely to trust any sort of deal the government may offer.

The literature suggests ways to tackle the inherent uncertainty of commitments to peace. Walter points out, for example, that signalling peaceful intentions credibly in the absence of a third-party monitor is very difficult, particularly during demobilization periods. ${ }^{9}$ Peacekeeping missions can thus be an important element in mitigating the problem of credible commitments to peace. ${ }^{10}$ Interventions of this type allow for independent monitoring of demobilization efforts and help to reduce the likelihood of conflict recurrence. ${ }^{11}$

Another possible path is to share political power. Hartzell and Hodie posit that power-sharing agreements are an effective way to mitigate contentious security situations. ${ }^{12}$ Power-sharing institutions are the set of rules that allocate decision-making rights and resources among groups competing for power. Examples are mechanisms of mutual veto, territorial autonomy, and proportional representation. A balance of power among former belligerents can serve as some guarantee that hostilities are unlikely to return. Such arrangements may reduce the need for high levels of military spending.

Power-sharing has some overlap with discussions on the effects of democratization in post-conflict settings. Walter, for instance, argues that conflict recurrence is less likely among democracies than other forms of government because of political participation. ${ }^{13}$ Democracies provide the institutional means through which groups can address their grievances. Recent research has found that democratic institutions lend the commitments of those in power greater credibility among constituents who might become 'agents of rebellion' in the future. ${ }^{14}$ Electoral institutions allow constituents to remove the incumbent government without having to resort to violence. For its part, the incumbent government will generally pre-emptively moderate its policies based on this possibility. The absence of elections can thus incentivize constituents to remove those in power through violent means. The prospect of insurrection often prompts the incumbent government to increase military spending. ${ }^{15}$ There is also evidence suggesting that democratizing

\footnotetext{
${ }^{8}$ Filson,D. and Werner, S., 'A bargaining model of war and peace: Anticipating the onset, duration, and outcome of war', American Journal of Political Science, vol. 46, no. 4 (Oct. 2002), pp. 819-38.

${ }^{9}$ Walter, B. F., 'Designing transitions from civil war: Demobilization, democratization, and commitments to peace', International Security, vol. 24, no. 1 (summer 1999), pp. 127-55.

${ }^{10}$ Doyle, M. W. and Sambanis, N., 'International peacebuilding: A theoretical and quantitative analysis', American Political Science Review, vol. 94, no. 4 (2000), pp. 778-801.

${ }^{11}$ DeRouen, Jr, K., 'The duration and recurrence of civil war', eds E. Newman and K. DeRouen, Jr, Routledge Handbook of Civil Wars (Routledge: London, 2014).

${ }^{12}$ Hartzell, C. and Hoddie, M., 'Institutionalizing peace: Power sharing and post-civil war conflict management', American Journal of Political Science, vol. 47, no. 2 (Apr. 2003), pp. 318-32.

${ }^{13}$ Walter, B. F., 'Does conflict beget conflict? Explaining recurring civil war', Journal of Peace Research, vol. 41, no. 3 (May 2004), pp. 371-88.

${ }^{14}$ Fjelde, H., Knutsen, C. H. and Nygård, H. M., 'Which institutions matter? Re-considering the democratic civil peace', International Studies Quarterly, vol. 65, no. 1 (Mar. 2021), pp. 223-37.

${ }^{15}$ D'Agostino, G., Dunne, J. P. and Pieroni, L., 'Military expenditure, endogeneity and economic growth', Defence and Peace Economics, vol. 30, no. 5 (2019), pp. 509-24.
} 


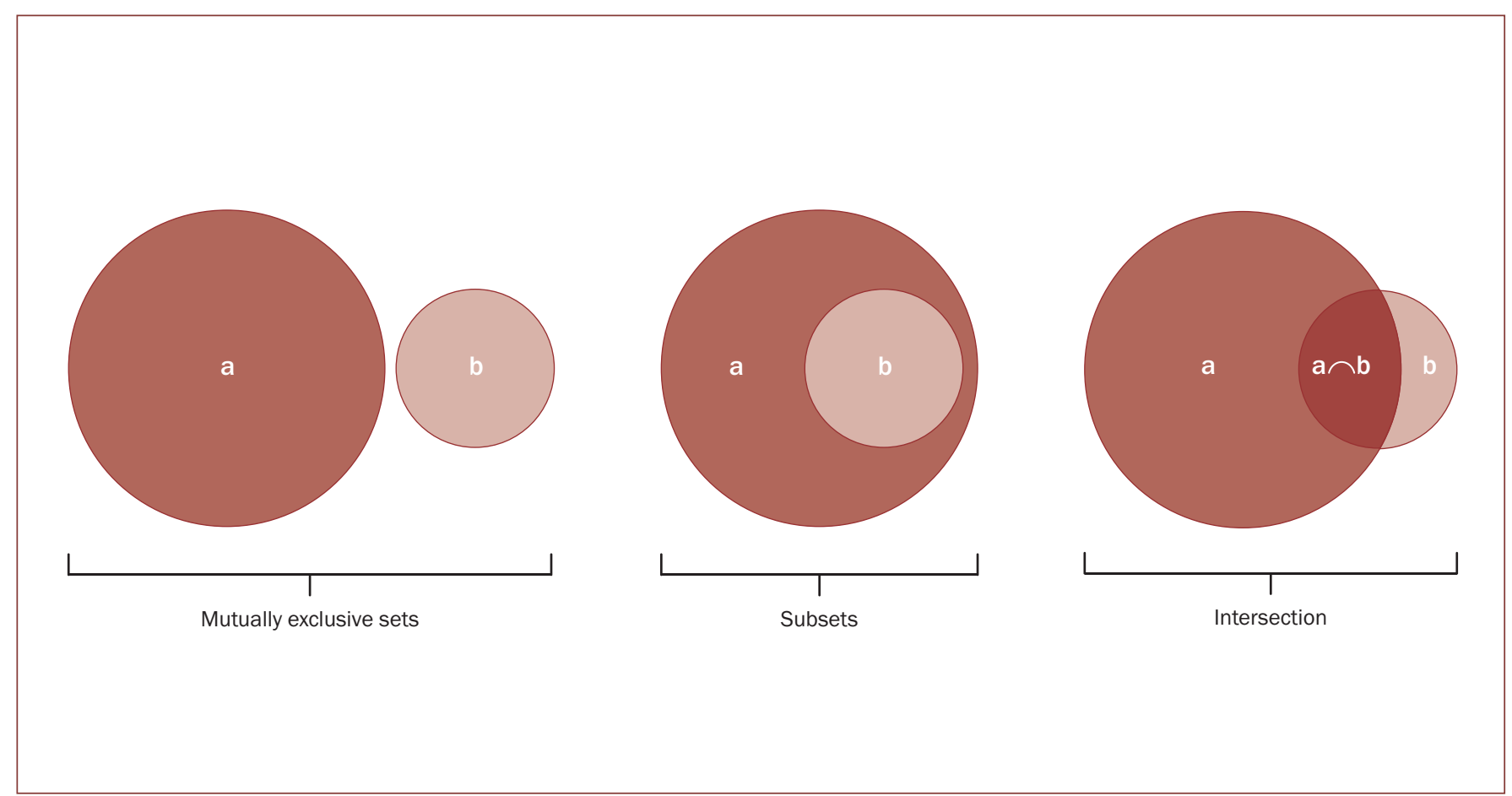

Figure 1. The relationships between sets

countries are particularly prone to civil conflict. However, recent research on the measurement of democracy has weakened this finding. ${ }^{16}$

A civil conflict's termination type (see section III) and how that termination type addresses credible commitment problems will largely influence the trajectory of military spending in subsequent years. Lockhart explores the effects of conflict termination types on military spending as a share of government expenditure. ${ }^{17}$ She hypothesizes that a clear military victory is conducive to reductions in military spending. Credible commitment is less of an issue if one of the warring parties has been decisively defeated. Her results suggest that government victories indeed lead to lower military spending. However, rebel victories have the opposite effect and lead to increases in military spending. Lockhart also finds that negotiated settlements and truces are correlated with reductions in military spending.

Although the main objective of their study is to examine the impact of civil conflict on military spending, Armey and McNab also explore whether specific types of conflict termination induce short-run military spending reductions. ${ }^{18}$ Their study finds that military spending as a share of government expenditure falls most acutely if a conflict terminates in a peace agreement. This is an interesting contrast to Lockhart. Whereas Armey and $\mathrm{McNab}$ find that a peace agreement is most strongly associated with reductions in military spending, Lockhart points to government victories. These contrasting results show that extant evidence on the types of conflict

\footnotetext{
${ }^{16}$ Boese, V. A., 'How (not) to measure democracy', International Area Studies Review, vol. 22, no. 2 (2019), pp. 95-127.

${ }^{17}$ Lockhart, S. P., 'The post-war dilemma: War outcomes, state capabilities, and economic development after civil war', Unpublished PhD dissertation, University of California, 2012.

${ }^{18}$ Armey, L.E. and McNab, R. M., 'What goes up must come down: Military expenditure and civil wars', Defence and Peace Economics, vol. 30, no. 5 (2019), pp. 570-91.
} 
termination that are most conducive to reductions in post-conflict military spending is still scant and divergent.

The following sections revisit this debate envisaging two main contributions. First, this SIPRI Insights paper relies on a set-theoretic approach to explain post-civil conflict military spending (i.e. it looks for specific sets of post-civil conflict conditions that are conducive to reducing military spending). ${ }^{19}$ In practice, this means recognizing that different combinations of conflict termination conditions can lead to military spending reductions. A second contribution concerns peace agreements. While previous research has considered the influence of peace agreements on post-civil conflict military spending, it has not addressed how diverse peace agreements can be. This study includes characteristics of peace agreements as additional conditions of conflict termination. It posits that the type of peace agreement and what it encompasses can also influence post-civil conflict military spending. This methodological option provides a more nuanced understanding about the role of peace agreements.

\section{Analytical strategy and data}

\section{Analytical strategy}

This study uses insights of set-theoretic methods to find consistent pathways to post-civil conflict military spending reductions. In practice, this means grouping cases with similar characteristics into sets and analysing their similarities. For the purposes of this study, it means finding how different sets of conflict termination types are related to the set of post-civil conflict military spending reductions.

Sets can relate in multiple ways, of which three are of particular interest to this study (see figure 1). First, sets can be mutually exclusive. For instance, conflicts that ended in government victory will be grouped in a set that logically excludes all cases that ended in a different way, such as a rebel victory or a peace agreement. Second, sets can contain other sets. For example, if all post-civil conflict power-sharing agreements are part of peace agreements, but not all peace agreements entail post-civil conflict power-sharing, then post-civil conflict power-sharing agreements are a subset of peace agreements. A third type of relationship between sets is intersection. This means the overlap between the set of post-civil conflict military spending reductions and the various sets of conflict termination types. For instance, a large intersection between the set of conflicts that ended in a government victory and the set of post-civil conflict military burden reductions indicates that most government victories are followed by reductions.

The analysis of the relationships between sets in this paper is complemented by qualitative case studies (see section V). The case studies focus on the same variables of interest used to compare all post-civil conflict cases, while also looking for additional variables that may have been omitted. The purpose of these case studies is to illuminate types and characteristics of conflict termination and their relative influence on post-civil conflict military spending with more nuance. The cases under analysis either closely follow

\footnotetext{
${ }^{19}$ Schneider, C. Q. and Wagemann, C., Set-Theoretic Methods for the Social Sciences: A Guide to Qualitative Comparative Analysis (Cambridge University Press: Cambridge, 2012).
} 
Table 1. Case selection criteria for post-civil conflict episodes

\begin{tabular}{|c|c|c|}
\hline Criteria & Inclusion & Exclusion \\
\hline Time frame $^{a}$ & $\begin{array}{l}\text { The civil conflict started after or in } 1970 \\
\text { and ended before or in } 2010 \text {. }\end{array}$ & $\begin{array}{l}\text { The civil conflict began before } 1970 \text { or } \\
\text { ended after } 2010 \text {. }\end{array}$ \\
\hline Continuity of polity & $\begin{array}{l}\text { The polity in question existed as an } \\
\text { independent polity before the outbreak } \\
\text { of the civil conflict and continued to exist } \\
\text { as such after the conflict had ended. }\end{array}$ & $\begin{array}{l}\text { The polity in question did not exist prior } \\
\text { to the civil conflict or ceased to exist } \\
\text { after the conflict. }\end{array}$ \\
\hline Type of conflict & $\begin{array}{l}\text { The conflict is categorized as an } \\
\text { intrastate or internationalized internal } \\
\text { armed conflict. }{ }^{b}\end{array}$ & $\begin{array}{l}\text { The conflict is categorized as an } \\
\text { extrasystemic or interstate conflict. }\end{array}$ \\
\hline Civil conflict duration & $\begin{array}{l}\text { The civil conflict lasted for longer than } \\
1 \text { month. }\end{array}$ & $\begin{array}{l}\text { The civil conflict lasted for less than } \\
1 \text { month. }\end{array}$ \\
\hline Civil conflict termination & $\begin{array}{l}\text { The civil conflict has ended and is } \\
\text { characterized as such in the UCDP } \\
\text { Conflict Termination Dataset. }\end{array}$ & The civil conflict has not ended. \\
\hline Duration of post-civil conflict period & $\begin{array}{l}\text { At least } 10 \text { years have passed since the } \\
\text { end of the civil conflict episode without } \\
\text { recurrence or the onset of another type } \\
\text { of conflict. }\end{array}$ & $\begin{array}{l}\text { A conflict episode of any kind occurred } \\
\text { within } 10 \text { years of the end of the last civil } \\
\text { conflict episode. }\end{array}$ \\
\hline Availability of military spending data & $\begin{array}{l}\text { Military spending data is available for } \\
\text { the state in question for at least } 1 \text { year } \\
\text { during the civil conflict and for the entire } \\
10 \text {-year post-civil conflict period. }\end{array}$ & $\begin{array}{l}\text { Military spending data is unavailable for } \\
\text { the entire duration of the civil conflict } \\
\text { or any year during the } 10 \text {-year post-civil } \\
\text { conflict period. }\end{array}$ \\
\hline Quality of military spending data & $\begin{array}{l}\text { Military spending data for the period } \\
1970-2020 \text { is mostly continuous and } \\
\text { certain. }\end{array}$ & $\begin{array}{l}\text { Military spending data is highly } \\
\text { uncertain. }\end{array}$ \\
\hline
\end{tabular}

UCDP = Uppsala Conflict Data Program.

${ }^{a}$ The time frame starts in 1970 because military spending data before then is scarcer and more uncertain. It ends in 2010 because, in order to consider a 10-year post-civil conflict period, the conflict has to have ended 10 years prior to the most recent year for which military spending data is available (2020).

${ }^{b}$ The UCDP Conflict Termination Dataset distinguishes between these two types of civil conflict.

${ }^{c}$ Extrasystemic conflicts are between a state and a non-state group outside the state's territory, where the government side is fighting to retain control of a territory outside the state system.

Sources: UCDP Conflict Termination Dataset, Version 2, 2015, accessed 17 July 2021; and Kreutz, J., 'How and when armed conflicts end: Introducing the UCDP Conflict Termination dataset', Journal of Peace Research, vol. 47, no. 2 (2010), pp. 243-50.

the most common pathway to military spending reductions or diverge the most from that pathway. ${ }^{20}$

\section{Definitions and data}

\section{What is a post-civil conflict episode?}

This study analyses post-civil conflict episodes in the period 1970-2020. A post-civil conflict episode refers to the first 10 years of uninterrupted peace following the end of a civil conflict episode. It starts in the first year

\footnotetext{
${ }^{20}$ Seawright, J. and Gerring, J., 'Case selection techniques in a menu of qualitative and quantitative options', Political Research Quarterly, vol. 61, no. 2 (2008), pp. 294-308.
} 
that a civil conflict no longer fulfils the Uppsala Conflict Data Program's (UCDP) definition of civil conflict. ${ }^{21}$ The decade-long duration of a post-civil conflict episode seeks to capture the persistent nature of military spending. Expenditure decisions made during conflict may take several years to cycle out, so a longer time horizon is needed to observe any meaningful changes.

The selection of cases from the UCDP's Armed Conflict Dataset was based on eight criteria, ranging from time frame to the quality of military expenditure data (see table 1). The application of these criteria produced a sample of 19 post-civil conflict episodes spanning 18 countries (see figure 2). It is worth noting, however, that these criteria may lead to some biases in the sample. For instance, by considering only civil conflicts that have formally ended, the data set may be skewed towards conflicts that culminated in peace agreements.

\section{How does a conflict end?}

The post-civil conflict episodes in the sample are coded with one of five different conflict termination types, each according to the UCDP's definitions: (a) peace agreement, (b) ceasefire agreement, (c) government military victory, (d) rebel military victory, and (e) low-intensity conflict.

A civil conflict ends in a peace agreement if all or the main parties active in the last year of conflict are signatories. Peace agreements aim to resolve the incompatibility that led to the conflict in the first place. Ceasefires, on the other hand, are more limited. A ceasefire is an agreement between all the main actors in a conflict that terminates military operations. ${ }^{22}$ As such, it only concerns the cessation of hostilities, not the incompatibility between the parties.

Government military victories take place if government forces manage to defeat or eliminate the opposition. Conversely, rebel military victories are those where rebel forces oust, comprehensively defeat or eliminate government forces. Simmering conflicts below the UCDP's 25 battle-related deaths per year threshold are coded as having ended in low-intensity conflict. $^{23}$

All post-civil conflict episodes that start with a peace agreement are also coded with some of its provisions. ${ }^{24}$ This provides a nuance that is not present in previous studies on the topic. The UCDP Peace Agreement Dataset covers nearly 40 characteristics of peace agreements. Based on the literature review, this study includes only those that are theoretically relevant to military spending reductions. They are characteristics that address powersharing, the creation of democratic institutions and the problem of credible

\footnotetext{
${ }^{21}$ The definition is (a) a contested incompatibility involving the government and one or more rebel forces; and (b) the use of armed force in an incompatibility that results in a minimum of 25 battle-related deaths in a calendar year. For more information on 'incompatibility', 'government', 'use of armed force' and 'battle-related deaths' see Uppsala Conflict Data Program (UCDP)/Peace Research Institute Oslo (PRIO), Armed Conflict Dataset Codebook, Version 21.1, 2021.

${ }^{22}$ Kreutz, J., 'How and when armed conflicts end: Introducing the UCDP Conflict Termination dataset', Journal of Peace Research, vol. 47, no. 2 (2010), pp. 243-50.

${ }^{23}$ For more information on conflict termination see UCDP Conflict Termination Dataset Codebook, Version 2, 2015, accessed 17 July 2021.

${ }^{24}$ For more information on peace agreements see UCDP Peace Agreement Dataset Codebook, Version 19.1, 2021.
} 


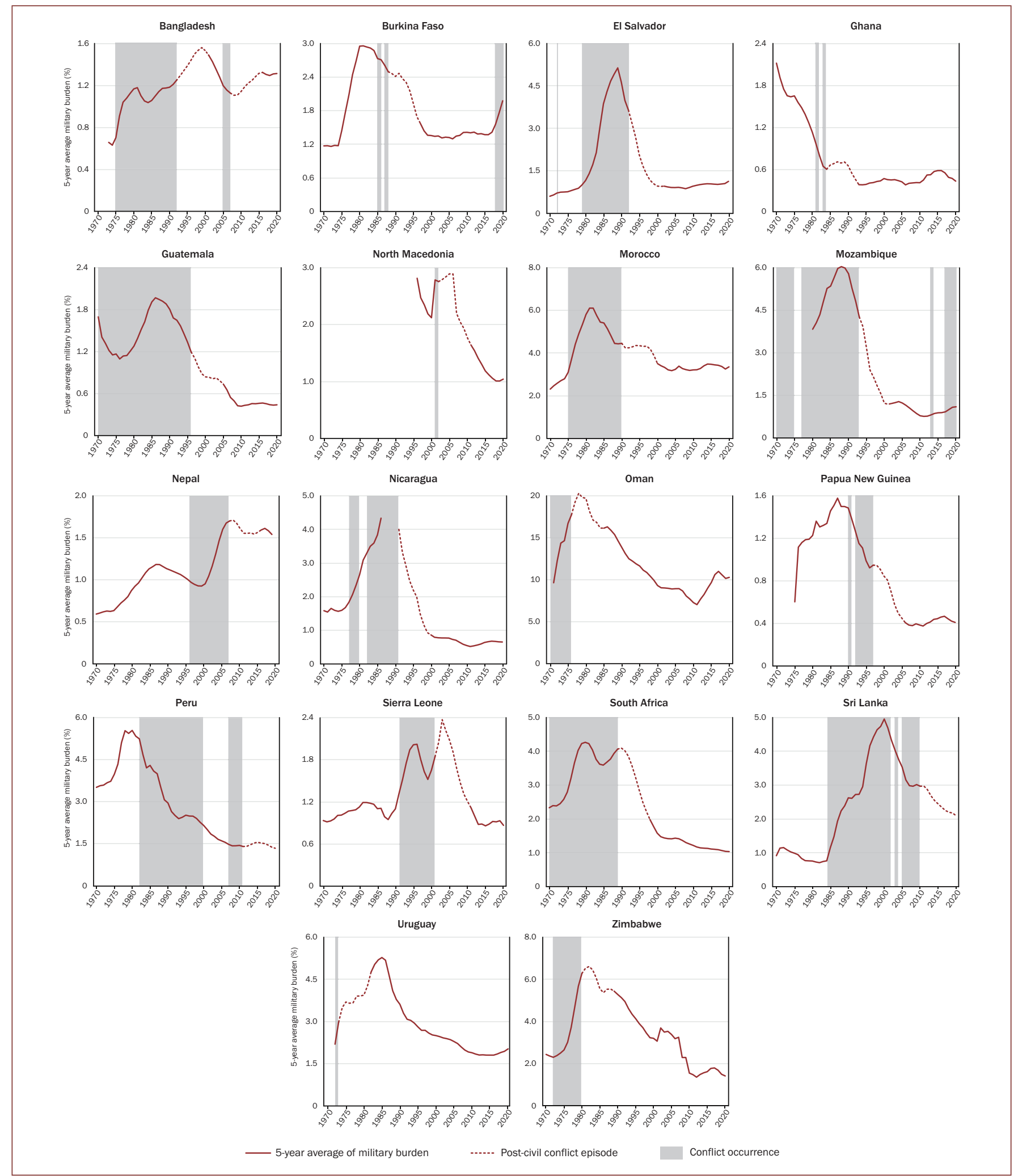

Figure 2. Sample of post-civil conflict episodes and military burden trajectories

Note: Lines are the 5-year average of military burden and areas in grey mark conflict occurrence. Dashed lines represent the first 10 years of the post-civil conflict episode.

Sources: SIPRI Military Expenditure Database, Apr. 2021, <https://www.sipri.org/databases/milex>; Pettersson, T. et al., 'Organized violence 1989-2020, with a special emphasis on Syria', Journal of Peace Research, vol. 58, no. 4 (July 2021); and Gleditsch, N. P. et al., 'Armed conflict 1946-2001: A new dataset', Journal of Peace Research, vol. 39, no. 5 (Sep. 2002), pp. 615-37. 
Box 1. The eight peace agreement characteristics used in the study

This study uses the following eight peace agreement characteristics in the Uppsala Conflict Data Program's (UCDP) Peace Agreement Dataset that are theoretically relevant to military spending reductions.

Ceasefire. The peace agreement includes provisions for a ceasefire or the cessation of hostilities. ${ }^{a}$

Disarmament, demobilization and reintegration (DDR). The peace agreement includes provisions for the disarmament of the warring parties.

Integration into the armed forces. The peace agreement includes the creation of a new national army or the integration of rebels into the national armed forces.

Military provisions. The peace agreement includes at least one of three other relevant categories, namely a ceasefire, integration of rebel troops into the national armed forces, or a DDR programme. ${ }^{b}$

Elections. The peace agreement provides for elections or stipulated electoral reforms.

National talks. The peace agreement includes provisions for holding national talks to solve incompatibilities.

Power-sharing in government. The peace agreement includes provisions for extensive power-sharing in the new government.

Peacekeeping operations. The peace agreement provides for the deployment of a peacekeeping operation.

${ }^{a}$ Ceasefires appear in this study as a peace agreement characteristic and as a conflict termination type. These two categories are different and should not be confused. In the first case, the conflict ended in a peace agreement that entailed a ceasefire, whereas, in the second case, the conflict itself ended in a ceasefire agreement. The category listed here is a ceasefire as a peace agreement characteristic, not as a conflict termination type.

${ }^{b}$ This is an adapted definition. In the UCDP Peace Agreement Dataset, military provisions also encompass withdrawal of foreign forces.

Sources: UCDP Peace Agreement Dataset, accessed 13 Jan. 2021; and Pettersson, T. and Öberg, M., 'Organized violence, 1989-2019', Journal of Peace Research, vol. 57, no. 4 (July 2020).

commitments to peace (see box 1 for a detailed list of the peace agreement characteristics used in this study).

It is important to note that the ceasefire category listed here as a peace agreement characteristic is different from a ceasefire as a conflict termination type (see box 1). In the first case, the conflict ended in a peace agreement that entailed a ceasefire, whereas, in the second case, the conflict itself ended in a ceasefire agreement. In addition, the military provisions category listed as a peace agreement characteristic is a meta-category, which means that it codes whether the peace agreement includes at least one of three other relevant categories, namely a ceasefire, integration of rebel forces into the national armed forces, or a disarmament, demobilization and reintegration (DDR) programme.

\section{What is a post-civil conflict military burden reduction?}

In this study, military spending is measured as a share of GDP (i.e. the military burden). ${ }^{25}$ This measure highlights the economic burden of military spending on post-civil conflict economic recovery. Its use here follows the literature on military spending and economic growth. ${ }^{26}$ Employing

\footnotetext{
25 TheSIPRIdefinition of military spendingincludes all currentand capital expenditure on $(a)$ the armed forces, including peacekeeping forces; $(b)$ defence ministries and other government agencies engaged in defence projects; (c) paramilitary forces, when judged to be trained and equipped for military operations; and $(d)$ military space activities. Civil defence and current expenditures on previous military activities, such as demobilization, disarmament and reintegration (DDR) are excluded. In the case of Sierra Leone, it includes the payment to military contractors hired by the government to fight on its behalf (see section $\mathrm{V}$ in this paper). For further information see the SIPRI Military Expenditure Database, <https://www.sipri.org/databases/milex>.

${ }^{26}$ Brauer, Dunne and Tian (note 4).
} 


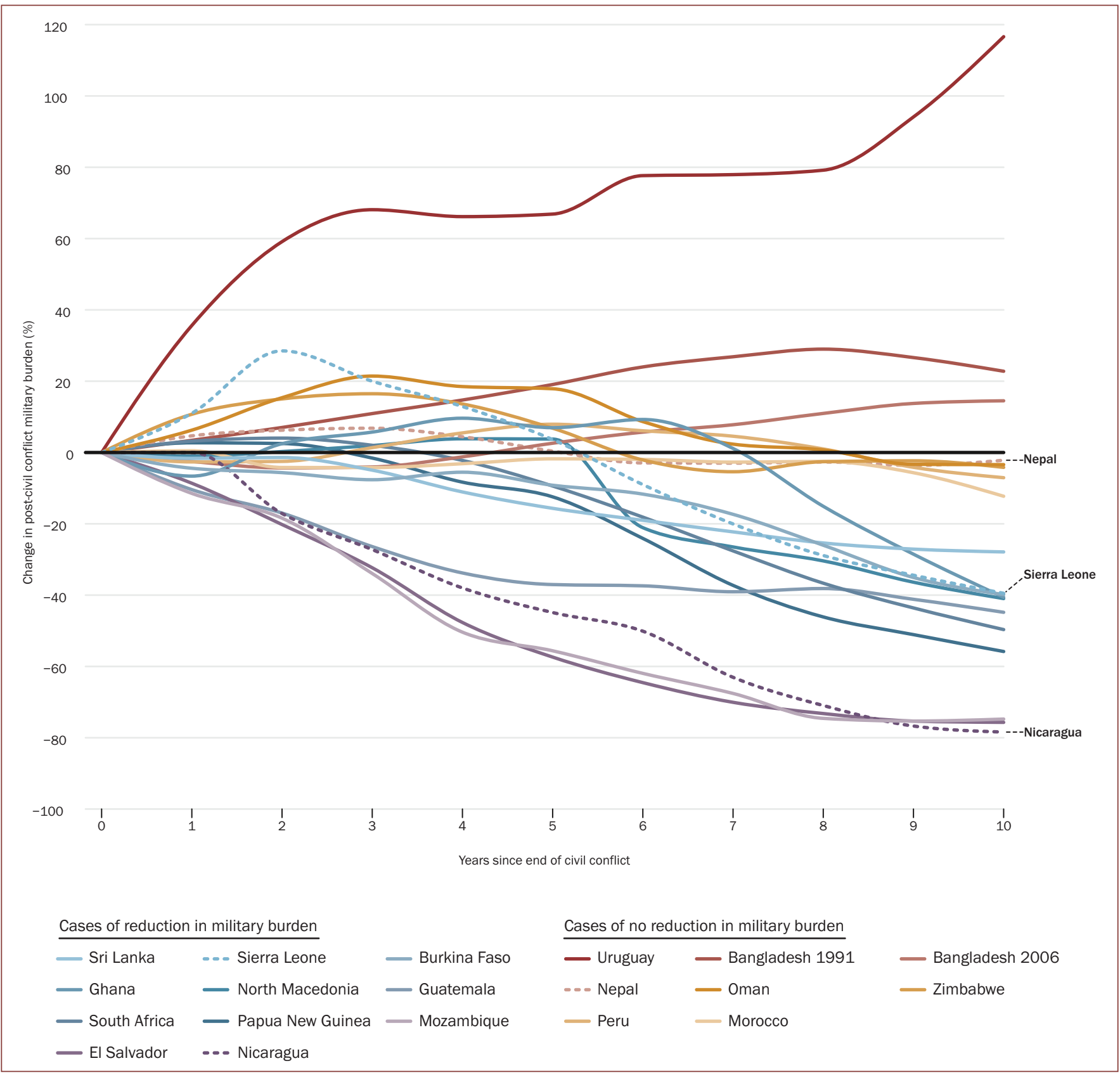

Figure 3. Military burden trajectories of post-civil conflict episodes

Note: Lines show the percentage change in average military burden compared with the last year of the civil conflict over a 10-year period. Dashed lines mark the case studies discussed in this paper. For the purposes of this study, post-civil conflict military burden trajectories must satisfy two criteria to be considered as reductions: at the end of the post-civil conflict decade, the military burden must be at least $25 \%$ lower compared with (a) its level in the last year of the conflict, and $(b)$ its average level during the conflict.

Source: SIPRI Military Expenditure Database, Apr. 2021, <https://www.sipri.org/databases/milex>.

military burden as a measure makes it easier to compare spending trends before, during and after a civil conflict. ${ }^{27}$ Some previous studies on post-

\footnotetext{
${ }^{27}$ Suppose reductions were assessed based on military spending as measured in constant local currency. In that case, each country must have a counterfactual military spending representing the level of the expenditure as if there was no civil conflict. The analysis would compare post-civil conflict military spending to the estimated level of the expenditure based on the no-civil-conflict counterfactual. The task of building credible counterfactuals and offering sensible comparison is
} 
conflict military expenditure have also used military spending as a share of government expenditure as a measure. However, SIPRI's data set in this category starts from 1988, which would lead to a much smaller sample of cases. This study uses military burden given as a five-year moving average to smooth the volatility of both GDP and military spending figures that would otherwise complicate trend assessments (see figure 2).

Defining what constitutes a reduction in military burden is a challenging task. For example, technically, both a 2 per cent and a 20 per cent decrease in military burden are reductions. However, they clearly differ in importance and potential consequences. This study is concerned with substantial reductions in military burden (i.e. those that could have a significant impact on post-conflict economic recovery). This would exclude minor cuts in military burden. Yet, previous research has not established any threshold to mark what constitutes a substantial reduction in military burden. Moreover, there are no theoretical arguments in the reviewed literature suggesting what this might be. Thus, any definition of what is meant by 'military burden reduction' inevitably has some degree of arbitrariness.

For the purposes of this Insights paper, post-civil conflict military burden trajectories must satisfy two criteria to be considered as reductions: at the end of the post-civil conflict decade, the military burden must be at least 25 per cent lower compared with (a) its level in the last year of the conflict, and $(b)$ its average level during the conflict. Only if both criteria are fulfilled can a post-civil conflict episode be recorded as a military burden reduction. The 25 per cent threshold was chosen mainly because it marks a natural gap in the data (see below and figure 3). Leveraging gaps in data is a common practice in set-theoretic studies to transform continuous variables into binary categories. ${ }^{28}$

Figure 3 in this paper traces the post-civil conflict military burden trajectories for individual cases compared with the last year of conflict. There are two main gaps between the lines below the zero mark (i.e. among the cases where military burden fell in the post-civil conflict period). The first gap in the data, from the bottom up, is between Mozambique, Nicaragua and El Salvador-the three cases with the biggest reductions-and the remaining cases. Using this gap to categorize cases of reduction would complicate the study because it would lead to a much too narrow definition of reduction-a decrease of over 75 per cent. The second gap in the data is better suited to this purpose. There is a clear separation between the group of countries clustered around a 55 per cent to 28 per cent reduction in military burden and the group of countries clustered around an 18 per cent to 2 per cent reduction. This gap marks a good division because it leads to a balanced split of cases. There

fraught with methodological challenges and would detract from the primary contribution of this study.

${ }^{28}$ Rihoux, B. and De Meur, G., 'Crisp-set qualitative comparative analysis (csQCA)', eds B. Rihoux and C. C. Ragin, Configurational Comparative Methods: Qualitative Comparative Analysis (QCA) and Related Techniques (Sage Publications: London, 2009), pp. 33-68; Li, Y., Kopenjan, J. and Verweij, S., 'Governing environmental conflicts in china: Under what conditions do local governments compromise?', Public Administration, vol. 94, no. 3 (2016), pp. 806-22; Vergne, J. P. and Depeyre, C., 'How do firms adapt? A fuzzy-set analysis of the role cognition and capabilities in US defense firms' responses to 9/11', Academy of Management Journal, vol. 59, no. 5 (2016), pp.1653-680; and Schneider, C. Q. and Wagemann, C., 'Standards of good practice in qualitative comparative analysis (QCA) and fuzzy-sets', Comparative Sociology, vol. 9, no. 3 (2010), pp. 397-418. 


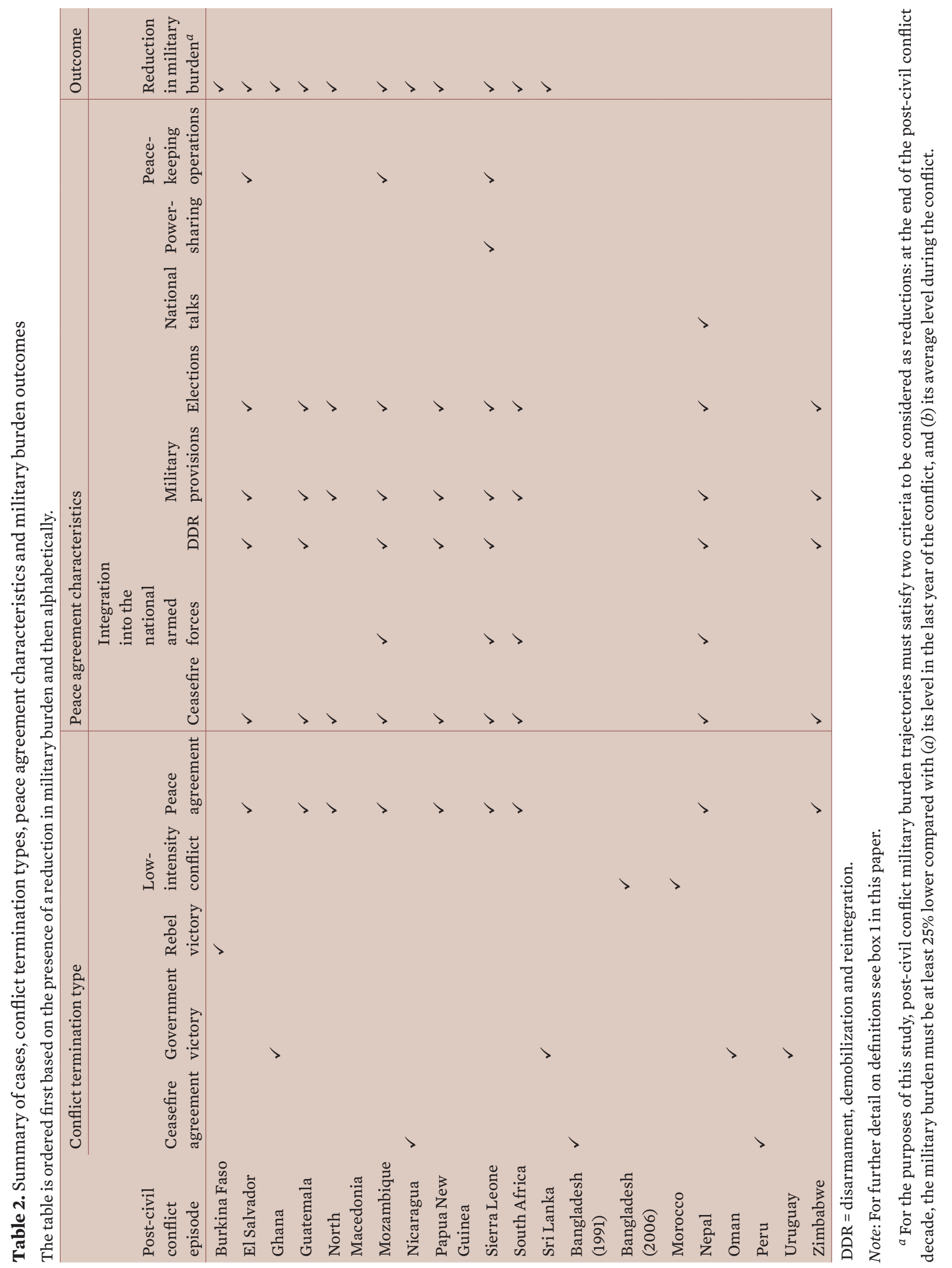


are 11 lines below the 28 per cent reduction mark: Burkina Faso, El Salvador, Ghana, Guatemala, Mozambique, Nicaragua, North Macedonia, Papua New Guinea, Sierra Leone, Sri Lanka and South Africa. Leveraging this division, this study sets a 25 per cent reduction as a threshold to categorize cases of post-civil conflict military spending reduction. In each of these 11 cases, the military burden at the end of the post-civil conflict decade was also at least 25 per cent lower than its average level during the conflict.

\section{Comparative analysis}

\section{Pathways to military burden reductions in post-civil conflict settings}

This section compares the conflict termination conditions of the 19 post-civil conflict episodes identified by this study and their respective military burden trajectories. Table 2 in this paper summarizes the conflict termination types, peace agreement characteristics (where relevant) and the military burden outcomes (i.e. whether there was a reduction) of all the cases in the sample. Using insights from set-theoretic methods, this section looks for the set of conditions with the largest and most consistent intersection with the set of post-civil conflict military burden reductions.

The analysis of the 19 post-civil conflict cases provides limited evidence supporting the association between government victories and reductions in military burden. Only four conflicts (or 21 per cent of the sample) ended with government victories-Ghana (1983), Oman (1975), Sri Lanka (2009) and Uruguay (1972) - of which only two led to reductions in military burden as defined by this study: Ghana in 1983 after the failed coup and Sri Lanka after the end of the civil conflict in 2009. In the case of Ghana, the military burden rose immediately after the coup attempt only to fall again from 1989 onwards. In addition, Ghana's military burden has followed a downward trend overall since at least 1970 . Thus, the reduction identified by this study seems to be a resumption of a pre-coup trend and not a consequence of the conflict termination type.

Ceasefire agreements are typically concerned with ending the use of force by the warring parties; thus, they do not include any resolution of the incompatibility that originally led to the conflict. As such, military burden reductions are not expected in these cases. Three conflicts in the sample ended as ceasefires: Bangladesh (1991), Peru (2010) and Nicaragua (1990), of which only the latter saw a post-civil conflict reduction in military burden. It is noteworthy, however, that Nicaragua had the largest military burden reduction in the sample: a decrease of 77 per cent compared with the last year of conflict. The reasons for this substantial reduction are explored in more detail in section $\mathrm{V}$ of this paper.

This study finds that peace agreements are associated with reductions in military burden. More specifically, peace agreements including military provisions (i.e. at least one of the following characteristics is present: a ceasefire, integration of rebel forces into the national armed forces, or a DDR programme) and elections are the predominant pathway to post-civil conflict military burden reductions. The set of cases with these characteristics is composed of nine conflicts, of which seven were followed by reductions in military burden (see figure 4). This combination is reasonably consistent: 


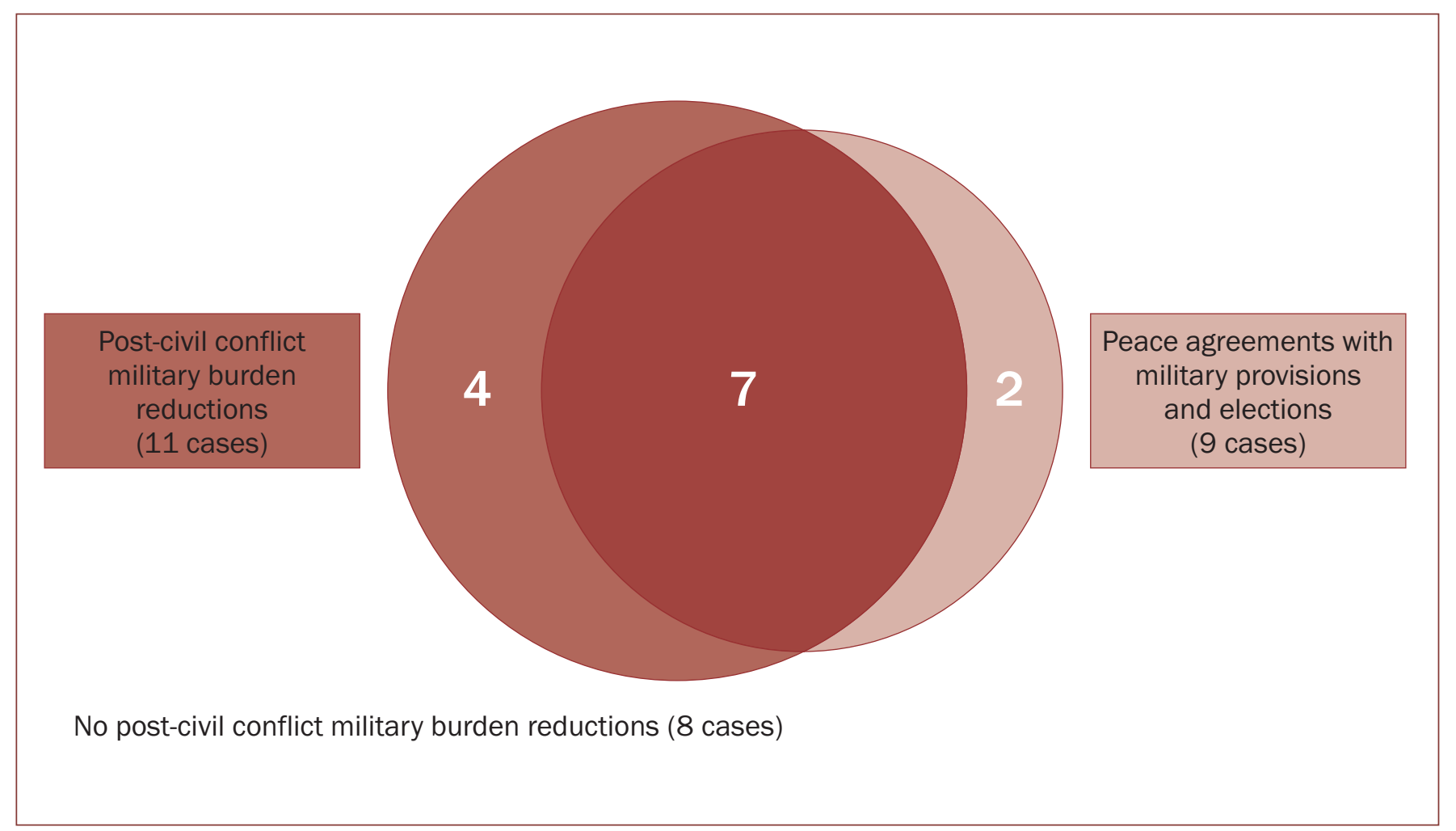

Figure 4. Intersection between sets of peace agreements and post-civil conflict military burden reductions

peace agreements that include military provisions and elections (9 cases) lead to military burden reductions ( 7 cases) nearly 80 per cent of the time. Its coverage is also fairly substantial: of all the cases in which there was a reduction in military burden (11 cases), 64 per cent of the time this involved a peace agreement with military provisions and elections ( 7 cases).

The end of Sierra Leone's civil conflict in 2001 represents a typical case of this pathway: the conflict ended with a comprehensive peace agreement that resolved the conflict and assured that the parties were credibly committed to peace. As expected, the military burden fell substantially in the years that followed (see section V). However, the same cannot be said about Nepal. While Nepal's conflict also ended with a comprehensive peace agreement akin to Sierra Leone's, its military burden remained at a much higher level compared with pre-conflict and conflict years. It remained relatively unaltered during the post-civil conflict decade and was only 2.2 per cent lower by the end of the 10-year period (see figure 3). In that sense, Nepal highlights that the existence of a comprehensive peace agreement is, in itself, insufficient to produce reductions in military burden as defined by this study (see section V).

The importance of peace agreements with the characteristics of military provisions and elections provides some support for the argument that military burden would fall in the presence of credible commitments to peace. Peace agreements are a reasonable approximation that the incompatibility that led to the conflict is, at least to some extent, resolved. ${ }^{29}$ While the final terms may not address the original demands of warring parties entirely, a peace agreement does signal a willingness to reach an arrangement that is

\footnotetext{
${ }^{29}$ Kreutz (note 22).
} 
satisfactory to all signatories at that point in time. Likewise, the inclusion of military provisions, such as ceasefires, DDR efforts and/or integration of rebel troops into the national armed forces, seems to serve as a credible signal that the parties are committed to peace. ${ }^{30}$

Elections also appear to be an important condition for military burden reductions. There are two likely reasons for this association. First, elections and other democratic institutions provide the means for a peaceful resolution of political disputes, further contributing to credible commitments to peace. ${ }^{31}$ Evidence shows that free, fair and competitive elections allow citizens to articulate their preferences and remove the incumbent government peacefully. Without such elections, violent uprisings may be the only way to change the country's leadership. ${ }^{32}$ Second, elections act as a vertical accountability mechanism, incentivizing the incumbent government to prioritize social expenditure over military spending in the hope of being re-elected. ${ }^{33}$

At first glance, the importance of elections may seem to be at odds with part of the literature on democratization and civil conflict. Collier and Hoeffler, for instance, find that while elections may reduce the risk of conflict recurrence in the year of election, they increase this risk in the following years. ${ }^{34}$ For its part, this risk is not conducive to a post-civil conflict reduction in military burden. However, in set-theoretic research, the effects of elections on conflict recurrence or military burden cannot be assessed independently from the other conditions at play. Available evidence on the negative effects of elections on post-conflict security is mostly derived from regression-based statistical methods, which means that the effect of elections is assessed while holding other conditions constant. This assumption tends to overlook the interaction of elections with other conditions. This is not the case with a settheoretic approach. The pathway identified in this section places elections alongside military provisions within the framework of a peace agreement. Therefore, although the individual effect of elections on military burden may be negative, its conjunction with other conditions seems to create a pathway for reductions in military burden.

One noteworthy issue with the pathway identified in this section is that all the relevant conditions (i.e. peace agreements with military provisions and elections) always appear together (see table 2). Consequently, it is difficult to assess, for instance, whether a peace agreement with military provisions alone would correlate with a post-civil conflict reduction in military burden. This problem is due to the limited diversity of the cases and is common in settheoretic research. ${ }^{35}$ It is often the case that because of certain structural

\footnotetext{
${ }^{30}$ Challenges to DDR efforts include the frequent phenomenon whereby rebel groups seek to recruit and inflate their armed forces to better position themselves in the peace process, and for DDR compensation. See e.g. Stibbe, P., 'Challenges to disarmament, demobilization and reintegration', E-International Relations, 2 Sep. 2012.

${ }^{31}$ Hegre, H., Bernhard, M. and Teorell, J., 'Civil society and the democratic peace', Journal of Conflict Resolution, vol. 64, no.1(2020), pp. 32-62.

${ }^{32}$ Fjelde, Knutsen and Nygård (note 14).

33 Przeworski, A., Stokes, S. C. and Manin, B., Democracy, Accountability and Representation (Cambridge University Press: Cambridge, 1999); and Brauner, J., 'Military spending and democracy', Defence and Peace Economics, vol. 26, no. 4 (2015), pp. 409-23.

${ }^{34}$ Collier, P., Hoeffler, A. and Söderbom, S., 'Post-conflict risks', Journal of Peace Research, vol. 45, no. 4 (July 2008), pp. 461-78.

${ }^{35}$ Schneider and Wagemann (note 19).
} 
features of social phenomena, a condition A would hardly ever happen without a condition B. ${ }^{36}$ This affinity between conditions inevitably limits the diversity of observed cases-some combinations of conditions simply do not happen or occur only rarely. However, it is also important to stress that the limited diversity of cases in the sample does not severely weaken, much less invalidate, the results. The combination of peace agreements with military provisions and elections remains a valid pathway despite the limited diversity of cases.

\section{Case studies}

Although the results of this study suggest that peace agreements with the characteristics of military provisions and elections are the most common pathway to military burden reductions, a more in-depth assessment is still needed to probe this finding. ${ }^{37}$ With that in mind, this section conducts qualitative analyses of the cases of Sierra Leone, Nepal and Nicaragua.

Sierra Leone follows closely the pathway identified in the previous section. The conflict ended with a peace agreement that entailed military provisions and elections. This was followed by a reduction in military burden as defined by this study. A closer examination of Sierra Leone's post-civil conflict episode therefore helps to provide a deeper and more nuanced understanding of how the combination of these conditions influences military burden.

The post-civil conflict periods in Nepal and Sierra Leone share important traits. Conflicts in both countries ended with peace agreements that encompassed military provisions and elections. However, the countries' post-civil conflict military burden trajectories differ significantly. Nepal's military burden remained close to wartime levels throughout the post-civil conflict decade. Thus, Nepal clearly deviates from the pathway followed by most other cases with similar conflict termination conditions. The case study on Nepal shows that the existence of a peace agreement is, in itself, insufficient to produce reductions in military spending as defined by this study. It identifies other factors at play that explain Nepal's divergent military burden trajectory.

The post-civil conflict periods of Nicaragua and Sierra Leone also share similarities. For instance, military burden fell substantially in both countries once the conflict ended. However, unlike Sierra Leone, the conflict in Nicaragua concluded not with a peace agreement, but with a ceasefire agreement. This means that the predominant pathway to military burden reduction identified by this study fails to explain a very important case in the sample. An analysis of conflict termination conditions in Nicaragua sheds light on other factors that were not considered in the first part of the study. The main purpose is to identify alternative explanations for the steep reduction in Nicaragua's military burden.

\footnotetext{
${ }^{36}$ Grofman, B. and Schneider, C. Q., 'An introduction to crisp-set QCA with a comparison to binary logistic regression', Political Research Quarterly, vol. 62 (2009), pp. 662-72.

${ }^{37}$ Seawright and Gerring (note 20).
} 


\section{Sierra Leone}

Civil conflict broke out in Sierra Leone in 1991, when the Revolutionary United Front (RUF) took over large areas of territory in eastern and southern Sierra Leone and tried to overthrow the government. The resultant 11-year civil conflict claimed over 50000 lives, displaced half of the country's population and left thousands of victims of rape, assault and amputations. ${ }^{38}$ The conflict also disrupted the economy, ravaging what was already one of the poorest states in the world. ${ }^{39}$

The civil conflict in Sierra Leone was intrinsically linked to neighbouring Liberia. Charles Taylor-the president of Liberia at that time-provided financial, logistical, political and strategic support to the RUF. Efforts by the Sierra Leonean Army (SLA) and international forces to defeat the RUF were continuously hampered by the porous borders between Sierra Leone and Liberia: the RUF would often retreat into Liberia and then regroup, rearm and launch a renewed offensive.

Military spending rose substantially in the first four years of the civil conflict, initially peaking at 2.2 per cent of GDP in 1995, up by 0.9 percentage points compared with 1991. The rise in spending in that period coincided with a more proactive military response from the SLA and the contracting of a South African private military company, Executive Outcomes (EO), for roughly 18 months (May 1995-November 1996) to fight the RUF. The reported cost of hiring EO ranged from US $\$ 500000$ to $\$ 1.5$ million a month. ${ }^{40}$ By the time EO withdrew from Sierra Leone, it had received almost $\$ 16$ million, equal to the amount spent on the entire Sierra Leonean military the year before conflict broke out. ${ }^{41}$

After the failure of the 1996 Abidjan Peace Accord in 1997, the Nigeria-led Economic Community of West African States Monitoring Group (ECOMOG) became the first international peacekeeping force to intervene in Sierra Leone. ${ }^{42}$ ECOMOG's intervention ultimately failed to prevent the RUF from capturing Freetown in January $1999 .{ }^{43}$ Unable to defeat the RUF and under substantial international and regional pressure, the Sierra Leonean Government sought peace with the RUF in February 1999.44

The subsequent Lomé Peace Agreement signed in July 1999 made significant headway in the peace process. ${ }^{45}$ The agreement granted amnesty to the

\footnotetext{
${ }^{38}$ Bellows, J. and Miguel, E., 'War and local collective action in Sierra Leone', Journal of Public Economics, vol. 93, nos 11-12 (Dec. 2009), pp. 1144-57.

${ }^{39}$ Davis, V., 'Sierra Leone: Ironic tragedy', Journal of African Economies, vol. 9, no. 3 (Oct 2000), pp. 349-69.

${ }^{40}$ McNeil, Jr, D. G., 'Pocketing the wages of war', New York Times, 16 Feb. 1997; and Winslow, P., 'Why Africa's armies open arms to elite fighters from S. Africa', Christian Science Monitor, 19 Oct. 1995.

${ }^{41}$ Maciag, M., 'Engagement of Executive Outcomes in Sierra Leone-utility assessment', Security and Defence Quarterly, vol. 27, no. 5 (2019), p. 65; and Rubin, E., 'Saving Sierra Leone, at a price', New York Times, 4 Feb. 1999.

${ }^{42}$ Peace Agreement between the Government of the Republic of Sierra Leone and the Revolutionary United Front of Sierra Leone, signed at Abidjan, Côte d'Ivoire, 30 Nov. 1996.

${ }^{43}$ Osakwe, C. and Audu, B. N., 'The Nigeria led ECOMOG military intervention and interest in the Sierra Leone Crisis: An overview', Mediterranean Journal of Social Sciences, vol. 8, no. 4 (July 2017), pp. 107-15.

44 'Rebels “cautiously welcome” Kabbah's peace offer', New Humanitarian, 9 Feb. 1999.

45 Peace Agreement between the Government of Sierra Leone and the Revolutionary United Front of Sierra Leone, signed at Lomé, Togo, 7 July 1999.
} 
RUF, included a DDR programme and called for a power-sharing agreement between the Sierra Leonean Government and the RUF. In October 1999 the UN Security Council authorized the establishment of the UN Mission in Sierra Leone (UNAMSIL) to assist the parties in carrying out provisions of the agreement. ${ }^{46}$ Despite the comprehensive coverage of the agreement and the concessions it made to the RUF, fighting restarted in 2000. The RUF, with the continued support of Liberia, refused to disarm. ${ }^{47}$ As a consequence, the government responded and Sierra Leone's military burden rose again, peaking in 2002 at 2.5 per cent of GDP. ${ }^{48}$

The resumption of fighting made clear that ending Liberia's support to the RUF was paramount to reaching peace. To that end, the international community imposed (and in some cases renewed) sanctions on Liberia, including embargoes on its trade in arms and diamonds. ${ }^{49}$ Alongside these sanctions, the UN increased UNAMSIL's troop capacity from 6000 to 13000 , making it the largest UN peacekeeping operation up to that point. ${ }^{50}$ On behalf of the Sierra Leonean Government, the United Kingdom also intervened militarily until 2002.

The waning support from Liberia, as well as the military presence of the UK and the UN in Sierra Leone, severely weakened the RUF and forced the rebels to negotiate. ${ }^{51}$ Conditions were now ripe for salvaging the Lomé Peace Agreement. ${ }^{52}$ Two additional agreements were signed by the Sierra Leonean Government and the RUF in November 2000 and May 2001. The first agreement recommitted the parties to the Lomé Peace Agreement and declared a new ceasefire. The second led to a robust programme of DDR, overseen by UNAMSIL. ${ }^{53}$ On 18 January 2002 President Ahmad Tejan Kabbah declared the official end of the conflict and called for elections to be held in May 2002.

The military burden fell substantially in the ensuing post-civil conflict years. From a peak of 2.5 per cent of GDP at the end of the civil conflict, the country's military burden fell to 1.0 per cent of GDP in 2011 and, by 2020, it was down to 0.6 per cent. The immediate fall in Sierra Leone's military burden after the 2002 peak reflects the significant shift in political conditions around that time, which became far more favourable to peace.

The continued military presence of the UK and the international forces of the UN after the conflict ended helped to mitigate credible commitment problems. ${ }^{54}$ UNAMSIL acted as a third-party monitor overseeing the peace

\footnotetext{
${ }^{46}$ UN Security Council Regulation 1270, 22 Oct. 1999.

${ }^{47}$ Reno, W., 'No peace for Sierra Leone', Review of African Political Economy, vol. 27, no. 84 (June 2000), pp. 325-29.

${ }^{48}$ Mitton, K., 'Elite bargains and political deals project: Sierra Leone case study', British Government, Stabilisation Unit, Feb. 2018.

${ }^{49}$ Arms Control Association, 'UN Imposes Arms Embargo on Liberia', Arms Control Today, 7 Mar. 2001.

${ }^{50}$ World Peace Foundation, 'United Nations mission in Sierra Leone (UNAMSIL) brief', African Politics, African Peace, 2017.

${ }^{51}$ Keen, D., Conflict and Collusion in Sierra Leone (James Currey and Palgrave: Oxford and New York, 2005), pp. 267-76.

52 Keen (note 51), pp. 267-76.

${ }^{53}$ Hayner, P., Negotiating Peace in Sierra Leone: Confronting the Justice Challenge (Centre for Humanitarian Dialogue: Geneva, Dec. 2007).

${ }^{54}$ United Nations, Department of Public Information, 'Disarmament, demobilization and reintegration: An essential component of peacekeeping', Fact Sheet 8, 29 May 2003.
} 
process and DDR programme, and the UK led a security sector reform initiative. ${ }^{55}$ In addition, the UK made it clear that it would intervene if conflict broke out again. ${ }^{56}$ Besides military provisions and elections, the peace agreement included power-sharing arrangements, which are also known to ameliorate credible commitment problems. ${ }^{57}$

The elections in May 2002 were an important part of the transition towards peace. The primary concern of voters was the termination of the conflict. ${ }^{58}$ The participation of the RUF in the 2002 elections helped to legitimize the post-civil conflict political process. While the incumbent President Kabbah of the Sierra Leone People's Party (SLPP) was re-elected with over 70 per cent of the votes, the most telling result was the failure of the RUF to win a single seat in parliament. The results of the 2002 election reflected the public perception of the RUF and its brutal role in the civil conflict. ${ }^{59}$

The return of multiparty democracy and the subsequent improvement in the budgetary process contributed to the sharp reduction of Sierra Leone's military burden. During military and single-party rule, the military received resources that were siphoned off state revenue. This was possible because the government managed to sidestep auditing public expenditure. Since 2001, Sierra Leone's budgetary process has become more consultative, with parliamentary oversight. ${ }^{60}$

Two other decisive factors not covered in the comparative analysis outlined in the previous section influenced Sierra Leone's post-civil conflict peace and thus military burden. First, the international efforts to improve regional stability played an important part in the reduction of the military burden. The removal of President Taylor from Liberia in 2003 significantly improved regional security and was a vital element to sustainable peace in the Mano River Basin. ${ }^{61}$ Second, prior field research has found that the collective determination of Sierra Leoneans to forgive and forget the past helped to make it less likely that violence would resume. ${ }^{62}$

The case of Sierra Leone exemplifies the pathway to military burden reductions identified in the comparative analysis in this paper. It clearly shows the complex interactions and dependencies between the various postcivil conflict conditions. International involvement was crucial to oversee DDR efforts and to mitigate the problem of obtaining credible commitments

\footnotetext{
55 Keen (note 51), pp. 272-73.

${ }^{56}$ Ucko, D. H., 'When intervention works: The instructive case of Sierra Leone', War on the Rocks, 31 Aug. 2016.

${ }^{57}$ UCDP Peace Agreement Dataset Codebook, Version 19.1, 2021.

${ }^{58}$ Wai, Z. 'Elections and the challenges of democratization in Sierra Leone', ed. S. Adejumobi, National Democratic Reforms in Africa (Palgrave Macmillan: New York, 2015).

${ }^{59}$ Kandeh, J. D., 'Sierra Leone's post-conflict elections of 2002', Journal of Modern African Studies, vol. 41, no. 2 (2003), pp. 189-216.

${ }^{60}$ Gbla, O., 'Sierra Leone', eds W. Omitoogun and E. Hutchful, SIPRI, Budgeting for the Military Sector in Africa: The Processes and Mechanisms of Control (Oxford University Press: Oxford, 2006), pp. 180-96.

${ }^{61}$ Mitton (note 48), pp. 16-18.

${ }^{62}$ Mitton, K., 'A pragmatic pact: Reconciliation and reintegration in Sierra Leone', eds. K. Ainley, R. Friedman and C. Mahony, Evaluating Transitional Justice: Accountability and Peacebuilding in Post-conflict Sierra Leone (Palgrave Macmillan: London, 2015), pp. 217-40; Shaw, R., 'Rethinking truth and reconciliation commissions: Lessons from Sierra Leone', United States Institute of Peace, Special Report 130, Feb. 2005, p. 9; Bellows and Miguel (note 38), pp. 1144-57; and Keen (note 51) pp. 169-71.
} 
to peace. ${ }^{63}$ Elections also played an important role in legitimizing the postcivil conflict political process. The evidence suggests that it was precisely this combination of conditions that led to a post-civil conflict environment conducive to a lower military burden. Additionally, the Sierra Leonean peace process had some specificities not covered in the comparative analysis. Regional stability and bottom-up structures for reconciliation had a major influence on post-civil conflict peace and military burden.

\section{Nepal}

In February 1996 Nepal was plunged into a decade-long civil conflict when the Communist Party of Nepal-Maoist (CPN-M) launched its insurgency. The list of grievances was long. The Maoists demanded the abolition of the monarchy, an overhaul of, what they saw as, the country's 'bourgeois' parliamentary democratic institutions and the creation of a communist people's republic. ${ }^{64}$ Above all, what motivated the Maoist movement was widespread inequality and discrimination, which had both ethnic and caste dimensions. ${ }^{65}$

Before the onset of the civil conflict, Nepalese military spending was well below the global average. States spent an average of 2.6 per cent of their GDP on their armed forces in 1995. In contrast, Nepal's military burden stood at 0.9 per cent. However, during the civil conflict (1996-2006), the military burden grew, peaking at 1.9 per cent of GDP. Nepalese military expenditure rose by 205 per cent over the period, from $\$ 87$ million in 1996 to $\$ 265$ million in 2006. ${ }^{66}$ Nepal's military budget increased most sharply between 2001 and 2005 , which coincided with a general intensification of the conflict.

Talks between the belligerent parties started at the end of 2001 but encountered several obstacles, including the unwillingness of King Gyanendra to participate in the peace process. ${ }^{67}$ In 2005 the king dissolved the government led by Prime Minister Sher Bahadur Deuba and reasserted his absolute power. This triggered the creation of the Seven-Party Alliance (SPA), which united political parties belonging to the former ruling coalition and the opposition against the crown. The SPA would later cooperate with the Maoists to oust the king.

The dissolution of the government triggered mass protests against King Gyanendra's actions. His grip on power was further weakened by the halt of financial and materiel support by India and the West. Only China continued to supply arms to Nepal. ${ }^{68}$ By April 2006 the mounting internal and external pressure eventually forced the king to reinstate the elected parliament and

\footnotetext{
${ }^{63}$ Solomon, C. and Ginifer, J., 'Disarmament, demobilisation and reintegration in Sierra Leone', Center for International Cooperation and Security, University of Bradford, July 2008.

${ }^{64}$ Upreti, B. R. and Sapkota, B., Case Study on Nepal:Observations and Reflections on the Peace and Constitution-making Process (Swiss Peace: Bern, Feb. 2017), p. 1.

${ }^{65}$ Murshed, S. M. and Gates, S., 'Spatial-horizontal inequality and the Maoist insurgency in Nepal', Review of Development Economics, vol. 9, no.1(2005), pp.121-34.

${ }^{66}$ Values are in constant US dollars at 2019 prices. SIPRI Military Expenditure Database, Apr. 2021, <https://www.sipri.org/databases/milex>.

${ }^{67}$ Upreti and Sapkota (note 64), p. 17.

68 Jaiswal, P., 'Caught in the India-China rivalry: Policy options for Nepal', Institute of Peace and Conflict Studies, Issue Brief, no. 249 (Mar. 2014).
} 
renounce all executive power. ${ }^{69}$ The Comprehensive Peace Agreement (CPA) was signed in November 2006, thereby ending more than a decade of brutal armed conflict.

The peace process that ended the Nepalese civil conflict produced four major agreements that tackled a broad range of issues. ${ }^{70}$ In May 2006 the belligerent parties agreed to an all-encompassing ceasefire. ${ }^{71}$ The CPA, which was signed six months later, sought to turn this ceasefire into a longlasting arrangement. It foresaw the organization of free and fair elections, created a Truth and Reconciliation Commission to promote a national dialogue on peace, laid a roadmap for the DDR programme and dealt with issues related to the management of weapons and ammunition. By signing it, the Maoists agreed to abstain from violence, follow the rule of law and honour democratic values. ${ }^{72}$ In 2007 the UN dispatched a special political mission to monitor the implementation of DDR efforts in Nepal, as stipulated by the 2006 Agreement on Monitoring the Management of Arms and Armies. ${ }^{73}$ Some remaining challenges related to the reintegration and rehabilitation of ex-combatants were resolved by the Seven Point Agreement passed in $2011 .^{74}$

The Nepalese peace process is generally thought to have been quite successful. However, although this process put in place a series of comprehensive and robust peace agreements, Nepal's military burden did not fall and total military spending continued to increase. After the end of the conflict in 2006, the military burden remained close to the wartime level of around 1.6 per cent of GDP. Nepalese military expenditure rose by 77 per cent over the 10-year post-civil conflict period (2007-16). ${ }^{75}$ As this increase in military spending was accompanied by a period of accelerated economic growth, the military burden remained stagnant.

This trend can be attributed to a conjunction of factors. First, not all armed groups that had fought under the Maoist banner during the Nepalese civil conflict accepted the outcome of the peace process. Some of them eventually split from the Maoist movement in protest over the CPA. In 2009 the government issued a list of 109 armed groups active in Nepal, particularly in rural areas. ${ }^{76}$ While none of these groups has the reach or capabilities of the CPN-M, their continued presence does elevate the state's threat perception.

A second factor is the resurgence of the Madhesi movement after the conflict ended. The movement employed both violent and non-violent tactics to raise the political profile of the Madhesi ethnicgroup in the hope of creating an autonomous province. The Madhesi people, many of whom live in the lowland region of Terai, have been subjected to exclusion and discrimination

\footnotetext{
${ }^{69}$ Whitfield, T., 'Nepal's Masala peacemaking', eds S. von Einsiedel, D. M. Malone and S. Pradhan, Nepal in Transition: From People's War to Fragile Peace (Cambridge University Press: Cambridge, Apr. 2012), p. 155.

${ }^{70}$ Nepal Institute for Policy Studies, Nepal's Peace Process: A BriefOverview, Policy Paper, vol. 8 , no. 1 (Nepal Institute for Policy Studies: Kathmandu, July 2013).

${ }^{71}$ Code of Conduct for Ceasefire Agreed between the Government of Nepal and the CPN (Maoist), Gokarna, 25 May 2006.

72 Comprehensive Peace Accord Signed between Nepal Government and the Communist Party of Nepal (Maoist), 22 Nov. 2006.

73 Agreement on Monitoring the Management of Arms and Armies, 8 Dec. 2006.

${ }^{74}$ Seven Point Agreement, 1 Nov. 2011.

75 SIPRI Military Expenditure Database, Apr. 2021, <https://www.sipri.org/databases/milex>.

76 Thapa, D., 'Post-war armed groups in Nepal', eds. D. Thapa and A. Ramsbotham, Accord, no. 26 (Conciliation Resources: London, Mar. 2017), pp. 107-108.
} 
for many years. ${ }^{77}$ Their struggle for autonomy long predates the civil conflict. However, in 2007-2008, armed Madhesi groups proliferated and the region of Terai began to witness a spike in attacks. Between 2007 and 2012 , over 1600 people were killed as a result of fighting in the region. ${ }^{78} \mathrm{After}$ the adoption of the Nepalese Constitution in 2015, which failed to address the concerns of the Madhesi movement, mass protests ensued once again. Despite a decline in the level of violence in more recent years, the persistent tensions may factor into the government's decision to maintain a high level of military spending.

Regional tensions may also be at play. Due to its geographic location, bordering China to the north and India to the south, Nepal often finds itself entangled in the geopolitical rivalries between these two states. ${ }^{79}$ They, together with the United States, have long vied for influence in Nepal. ${ }^{80}$ China, for instance, has moved to deepen military cooperation with Nepal. To the south, India's occasional support of the Madhesi movement and ongoing territorial disputes along the shared border have strained relations. ${ }^{81}$ Nepal's concerns about these regional tensions may thus partly explain why its military burden remained at a relatively high level during the post-civil conflict decade.

Finally, it is worth noting that Nepal is a major troop contributor to UN peacekeeping missions. Nepal first dispatched peacekeeping troops in 1974 as part of the Second UN Emergency Force in the Sinai Peninsula. ${ }^{82}$ Since then, Nepal has drastically stepped up its contributions. Between 1990 and 2020, the number of Nepalese troops stationed with UN peacekeeping operations increased sixfold from 851 to $5132 .{ }^{83}$ In 2021 Nepal was the second largest troop contributor to UN peacekeeping missions worldwide. ${ }^{84}$ Costs related to the deployment of peacekeepers-although these are later reimbursed by the UN-may be another factor keeping Nepal's post-civil conflict military burden at a high level.

The case of Nepal shows that peace agreements with military provisions and elections do not automatically bring about a reduction in military burden. Ongoing domestic security threats, regional dynamics and other military-related costs (e.g. the deployment of peacekeepers) must also be considered. In Nepal, these factors were enough to counteract the potential benefits of comprehensive conflict termination conditions.

\section{Nicaragua}

The Sandinista National Liberation Front (Frente Sandinista de Liberación Nacional, FSLN) overthrew the authoritarian regime of Anastasio Somoza

\footnotetext{
${ }^{77}$ Kantha, P. K., 'Understanding Nepal's Madhesi movement and its future trajectory', Himalayan Journal of Development and Democracy, vol. 5, no. 1 (2010), pp. 31-40.

${ }^{78}$ Asia Foundation, The State of Conflict and Violence in Asia (Asia Foundation: Bangkok, 2017), p. 121.

${ }^{79}$ Jaiswal (note 68).

${ }^{80}$ Wagle, G. S., 'Triangular geopolitical rivalry', Kathmandu Post, 6 June 2021.

${ }^{81}$ Najar, N., 'Border havoc as Nepalis accuse India of payback', New York Times, 30 Sep. 2015.

${ }^{82}$ Nepali Army, 'The Nepali Army in UN peacekeeping operations', 19 July 2021.

${ }^{83}$ SIPRI Multilateral Peace Operations Database, <https://www.sipri.org/databases/pko>.

${ }^{84}$ THT Online, 'Nepal becomes 2nd largest troops-contributor to UN Peacekeeping missions', Himalayan Times, 20 July 2021.
} 
in 1979. However, violence erupted again shortly thereafter as opponents of the new government took up arms. The Contras, as the rebel forces would be known, were a relatively heterogeneous group. While former members of Somoza's National Guard comprised a large part of the opposition group, peasants in the Atlantic coast region and the ethnic minority of the Miskito also joined later. ${ }^{85}$ The conflict between the Sandinistas and the Contras lasted for over a decade, with disastrous consequences for Nicaragua's society and economy.

The civil conflict in Nicaragua had a clear international dimension. The USA actively supported the Contras with equipment, training and financial aid. The USA's main goal was to avoid the proliferation of left-wing governments in the region. The shadow of the Cuban revolution loomed large in the US containment strategy in Central America. ${ }^{86}$ At the time, the region became an important battleground of the cold war and similar conflicts were gaining momentum in El Salvador and Guatemala.

In addition to US support, the Contras in Nicaragua received assistance from neighbouring countries. Honduras and Costa Rica provided access to bases in their territories, becoming havens for the Contras. Honduras was particularly active in supporting the Contras. It is estimated that 7000 Contras were operating in Honduras by around $1983 .{ }^{87}$ The porous borders between these countries were a source of instability for the whole region. Nicaraguan government forces (Sandinistas) often followed Contra rebels into Honduras, infringing its sovereignty. This situation almost led to war between the two countries in 1988. Honduras threatened Nicaragua with airstrikes unless the Sandinistas withdrew from its territory, which they did 11 days after the ultimatum. ${ }^{88}$

The intensification of the conflict in the mid 1980s, alongside Nicaragua's increasing military burden and a US embargo, severely strained the economy. Nicaragua's average military burden rose to 4.3 per cent of GDP in 1985, at the height of the hostilities. The war effort consumed a significant part of the country's productive capacity: by around 1984, it is estimated that the military used 10 per cent of total manufacturing production and 20 per cent of the male workforce. ${ }^{89}$

Peace negotiations began as early as 1983 . The Contadora process sought to foster a dialogue between Central American countries to reduce tensions and lay the foundations of peaceful coexistence. The process, however, failed to achieve any meaningful progress and ended in 1986. Costa Rican President Oscar Arias Sánchez led a resumption of peace efforts in 1987. The Esquipulas Agreement in August of that year called for the end of neighbouring support for the Contras and democratization in Nicaragua. For its part, Nicaragua

\footnotetext{
85 Bulmer-Thomas, V., 'Nicaragua since 1930', ed. L. Bethell, The Cambridge History of Latin America: 1930 to the Present: Mexico, Central America and the Caribbean, vol. VII (Cambridge University Press: Cambridge, 2008), p. 358.

${ }^{86}$ Kryzanek, M. J., 'The US in Central America and the Caribbean', Bridgewater Review, vol. 2, no. 2 (1984), pp. 4-8.

87 Child, J., The Central American Peace Process, 1983-1991: Sheathing:Swords, Building Confidence (Lynne Rienner Publishers: Boulder, CO, Oct. 1992)

${ }^{88}$ Child (note 87 ).

${ }^{89}$ Ryan, P., 'Nicaragua's economy: The dilemmas of a revolution at war', Canadian Association of Latin American and Caribbean Studies, vol. 11, no. 22 (1986), pp. 37-58.
} 
stressed the need for a UN-led mission to monitor the implementation of the agreement. ${ }^{90}$

Honduras's commitment to the Esquipulas Agreement was crucial. Although initially hesitant, Honduras eventually agreed to implement the terms of the agreement and began to expatriate the Contras based in its territory. Ultimately, this forced the Contras to negotiate with the Nicaraguan Government. The Contras were included in the peace talks only from 1988, after the Esquipulas Agreement. In March of that year, the Sandinistas and the Contras agreed to a ceasefire and peace talks. However, the ceasefire failed, and violence broke out again a few months later. ${ }^{91}$

Despite the failure of the 1988 ceasefire, peace negotiations were gaining momentum. In 1989 Nicaragua agreed to hold elections in 1990 if Honduras closed all Contra bases in its territory. The commitment of the Nicaraguan Government to stage free and fair elections met an important demand of its neighbours and the Contras. That same year, the Tela Declaration called for an international mission to monitor disarmament efforts. Soon after, the UN Security Council approved the creation of the UN Observer Group in Central America (ONUCA). Importantly, ONUCA was based in Honduras. This choice was critical to build trust in the disarmament process since the Sandinistas could not verify demobilization in Honduran territory. ${ }^{92}$

The Sandinistas upheld their commitment and organized elections in February 1990. Violeta Chamorro, the main leader of the National Opposition Union (Unión Nacional Opositora, UNO) coalition, won the presidental election. In her first presidential address, Chamorro called on the Contras to disband. With support from the USA withering and unable to retreat into neighbouring countries, the Contras were not in a position to fight. The elections and the victory of Chamorro also gave them a pathway to achieve their political goals without resorting to violence. ${ }^{93}$ In May 1990 the Contras signed a ceasefire agreement, the Managua Protocol on Disarmament, with the Chamorro Administration, officially ending their armed struggle. The Contras had been almost completely demobilized by the end of June, marking the end of Nicaragua's civil conflict.

In the years that followed, military spending fell sharply. President Chamorro ordered the military to reduce its size, a key demand of the Contras. Between 1990 and 1994, Nicaragua cut the number of military personnel by 83 per cent. ${ }^{94}$ The reduction was, moreover, part of a regional agreement to curb arms imports and to reach military parity among neighbours. ${ }^{95} \mathrm{It}$ was also, to a large extent, an economic necessity. The many years of high military burden had taken a toll on Nicaragua's economy.

The Managua Protocol on Disarmament was a landmark for the end of Nicaragua's civil conflict. The peace process was much broader, however. While the protocol (a ceasefire agreement rather than a comprehensive

\footnotetext{
90 Child (note 87).

${ }^{91}$ Child (note 87 ).

92 Child (note 87)

93 Child (note 87); and Spencer, D., 'Demobilization and reintegration in Central America', Bonn Center for International Conversion, Paper 08, Feb. 1997, pp. 1-77.

94 Cajina, R. J., Transición Política y Reconversión Militar en Nicaragua, 1990-1995 [Political Transition and Military Reconversion in Nicaragua, 1990-1995] (Coordinadora Regional de Investigaciones Económicas y Sociales, CRIES: Managua, 1996).

95 Child (note 87), p. 111
} 
peace agreement) itself does not fit the pathway identified in the comparative analysis in the previous section, the peace process as a whole does. First, disarmament efforts were at the heart of negotiations. ONUCA played a critical role in verifying disarmament and thus mitigating the problem of obtaining credible commitments to peace. Second, elections were very important in the process. Chamorro's victory in 1990 meant that opponents could use political means to address their grievances and seek their political goals. These conditions, alongside improvements in regional relations, were conducive to a reduction in military burden after the conflict ended.

\section{Conclusions}

In 2020 the number of active conflicts reached its highest level since the end of the cold war. ${ }^{96}$ For years to come, the challenge will be to bring these conflicts to an end as well as to ensure the recovery of conflict-affected states. The legacy costs of these conflicts will be significant, and policymakers will need solid evidence on how to address them if progress is to be made. To assist with this task, this SIPRI Insights paper offers relevant findings on post-civil conflict reductions of military burden.

Countries emerging out of civil conflict face two main challenges: economic recovery and the risk of conflict recurrence. ${ }^{97}$ The ongoing efforts to reduce excessive military spending led by the UN must consider how these elements are intertwined. While striving for a broad message in their advocacy, UN entities and civil society organizations should also acknowledge the need for a distinctive strategy for conflict-affected states. The study presented in this paper could inform this strategy, stressing the importance of conflict termination conditions on post-civil conflict military burden.

The comparative analysis of conflict termination conditions and military burden outcomes shows that peace agreements with military provisions and elections are the predominant pathway to post-civil conflict military burden reductions. This pathway covers 7 of the 11 cases of post-civil conflict military burden reductions in this study. This is mainly because such conditions address two key problems of post-civil conflict settings. First, they mitigate the problem of credible commitment. Peace settlements are inherently uncertain, and belligerents may fear that, if they disarm, the other party will take the opportunity to strike. Military provisions, such as DDR efforts or the integration of rebels into the national armed forces ameliorate these concerns. Second, elections help to legitimize the political process and offer an avenue to solve grievances peacefully. Moreover, electoral accountability is known to constrain military burden. Democratically elected officials have more of an incentive to allocate funding to social goods such as health or education rather than to the military.

The three case studies in this paper complement the comparative analysis in several ways. For instance, the case of Nepal shows that other factors, such as the presence of splinter groups, can be just as important to postcivil conflict military burden as the conflict termination conditions in the pathway identified by the comparative analysis. The case of Nicaragua, on

\footnotetext{
${ }^{96}$ Strand, H. and Hegre, H., 'Trends in armed conflict, 1946-2020', Peace Research Institute Oslo (PRIO), Conflict Trends, vol. 3, 2021.

${ }^{97}$ Collier, Hoeffler and Söderbom (note 34), pp. 461-78.
} 
the other hand, provides an explanation for a steep military burden reduction that was not preceded by a comprehensive peace agreement. A more detailed assessment of this case, however, reveals that all the important conditions associated with post-civil conflict military burden reductions were present, albeit not coded in the UCDP Conflict Termination Dataset. This, of course, is not a problem of the data set per se, but instead reflects a more general issue when working with large amounts of codified information. Often, coding decisions must be made at the expense of a more complex depiction of events. Although this is not a reason to avoid using large data sets, it is an argument to complement their use with more nuanced analysis.

Another contribution of the case studies concerns the regional dimension. Both in Nicaragua and in Sierra Leone, resolving issues with neighbouring states was a critical part of the domestic peace process. In both cases, neighbouring states played a role in the conflict, either by supporting rebels with armaments and training or by providing a haven for their activities. In Nepal, the continued Indian support of the Madhesi movement also exemplifies how regional relations interfere with domestic conflicts and therefore prolong higher military burden levels.

Economic factors, such as revenue extraction, economic growth or indebtedness, were not fully addressed in this paper. Admittedly, these elements can influence decisions to reduce post-civil conflict military burden. For instance, impaired tax capacity can lead to lower levels of public expenditure. Likewise, debt can enable higher levels of military spending despite a weak tax effort. However, the methodology employed in this paper has an affinity with qualitative variables, such as memberships in sets and types of conflict termination, to the detriment of quantitative variables, such as a country's wealth. Future research should try to incorporate economic factors into the analysis using other tools, such as fuzzy sets. ${ }^{98}$

Another future research avenue is to explore the variation across cases of post-civil conflict military burden reduction. For example, El Salvador and Ghana were both categorized as cases of reduction. However, reduction in the former was much greater than in the latter. Although this study finds evidence on what could explain post-civil conflict military burden reductions, it does not shed light on why some reductions are bigger than others. Future research on the matter should look to address this heterogeneity.

\footnotetext{
${ }^{98}$ In fuzzy sets, membership is not binary but ranges from 0.0 (non-membership) to 1.0 (full membership). As such, cases vary in the degree to which they satisfy membership criteria. This is particularly helpful to code conditions that cannot be easily dichotomized, such as a country's wealth. In this case, it would be possible to use different membership scores to code countries across different income groups (i.e. high income, upper-middle income, lower-middle income and low income). Ragin, C. C., The Comparative Method: Moving Beyond Qualitative and Quantitative Strategies (University of California Press: Oakland, CA, 1987).
} 


\author{
Abbreviations \\ CPA Comprehensive Peace Agreement \\ CPN-M Communist Party of Nepal-Maoist \\ DDR Disarmament, demobilization and reintegration \\ ECOMOG Economic Community of West African States Monitoring \\ Group \\ EO Executive Outcomes \\ FSLN Frente Sandinista de Liberación Nacional (Sandinista \\ National Liberation Front) \\ GDP Gross domestic product \\ ONUCA UN Observer Group in Central America \\ RUF Revolutionary United Front \\ SLA Sierra Leonean Army \\ SLPP Sierra Leone People's Party \\ SPA Seven-Party Alliance \\ UCDP Uppsala Conflict Data Program \\ UN United Nations \\ UNAMSIL UN Mission in Sierra Leone \\ UNO Unión Nacional Opositora (National Opposition Union)
}


SIPRI is an independent international institute dedicated to research into conflict, armaments, arms control and disarmament. Established in 1966, SIPRI provides data, analysis and recommendations, based on open sources, to policymakers, researchers, media and the interested public.

\section{GOVERNING BOARD}

Ambassador Jan Eliasson, Chair (Sweden)

Ambassador Chan Heng Chee

(Singapore)

Jean-Marie Guéhenno (France)

Dr Radha Kumar (India)

Dr Patricia Lewis (Ireland/

United Kingdom)

Dr Jessica Tuchman Mathews

(United States)

Dr Feodor Voitolovsky (Russia)

\section{DIRECTOR}

Dan Smith (United Kingdom)

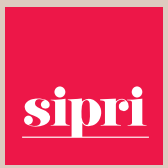

STOCKHOLM INTERNATIONAL PEACE RESEARCH INSTITUTE Signalistgatan 9 SE-169 72 Solna, Sweden Telephone: +4686559700 Email:sipri@sipri.org Internet: www.sipri.org
SIPRI INSIGHTS ON PEACE AND SECURITY NO. 2022/1

\section{PATHWAYS FOR REDUCING MILITARY SPENDING IN POST-CIVIL CONFLICT SETTINGS}

DIEGO LOPES DA SILVA, NAN TIAN AND ALEXANDRA MARKSTEINER

\section{CONTENTS}

I. Introduction

II. Military spending in post-civil conflict settings 2

III. Analytical strategy and data $\quad 5$ Analytical strategy $\quad 5$

Definitions and data 6

IV. Comparative analysis 13

Pathways to military burden reductions in post-civil conflict settings 13

$\begin{array}{ll}\text { V. Case studies } & 16\end{array}$

Sierra Leone $\quad 17$

Nepal 20

Nicaragua $\quad 22$

VI. Conclusions $\quad 25$

$\begin{array}{ll}\text { Abbreviations } & 27\end{array}$

Box 1. The eight peace agreement characteristics used in the study 9

Figure 1. The relationships between sets 4

Figure 2. Sample of post-civil conflict episodes and military burden trajectories 8

Figure 3. Military burden trajectories of post-civil conflict episodes 10

Figure 4. Intersection between sets of peace agreements and post-civil conflict $\quad 14$ military burden reductions

Table 1. Case selection criteria for post-civil conflict episodes 6

Table 2. Summary of cases, conflict termination types, peace agreement 12 characteristics and military burden outcomes

\section{ABOUT THE AUTHORS}

Dr Diego Lopes da Silva (Brazil) is a Senior Researcher with the SIPRI Military Expenditure and Arms Production Programme.

Dr Nan Tian (South Africa) is a Senior Researcher with the SIPRI Military Expenditure and Arms Production Programme.

Alexandra Marksteiner (Austria/Germany) is a Researcher with the SIPRI Military Expenditure and Arms Production Programme. 